\title{
PERTUMBUHAN BIBIT KALIANDRA PADA BEBERAPA KOMPOSISI MEDIA SEMAI CETAK DI PERSEMAIAN DAN LAPANGAN
}

\author{
Growth of Kaliandra Seedling on Different Block Seedling Media Compositions \\ in Nursery and Field
}

\author{
Eliya Suita, Dede J. Sudrajat dan/and Rina Kurniaty \\ Balai Penelitian dan Pengembangan Teknologi Perbenihan Tanaman Hutan Bogor \\ Jl. Pakuan Ciheulet PO BOX 105 Bogor, Jawa Barat, Indonesia \\ Email: eliyasuita@yahoo.co.id
}

Tanggal diterima: 8 Februari 2017; Tanggal direvisi: 4 Mei 2017; Tanggal disetujui: 12 Mei 2017

\begin{abstract}
Planting of $k$ aliandra (Caliandra calothyrsus Meissn.) is generally carried out by preparing the seedling using polybagwith top soil media. Large quantities of polybag may pollute the forest soil because polyethylene is difficult to be degraded. The research aimed to test ten compositions of block seedling media as a growth media for kaliandra seedlings in nursery and field. The research used randomized completely design for testing the effect of block seedling media compositions on (1) the strength of block ed seedling media; (2) growth of kaliandra seedlings in the nursery and field test. The result showed that the media composition KM-3 (mixed media of compost 40\%, rice hull charcoal 20\%, soil 20\%, lime 10\%, tapioca 10\%, rhizobium $3 \mathrm{~g}$ ), KM-7 (compost 30\%, rice hull charcoal 20\%, soil 30\%, lime 10\%, tapioca 10\%, rhizobium $3 \mathrm{~g}$ ) and KM-8 (compost 30\%, rice hull charcoal 20\%, soil 30\%, lime 10\%, tapioca 10\%, mycorrhizae $3 \mathrm{~g}$ ) had intactness media level more than 90\% after 2 months testing in nursery. Composition of KM-3 was the best growth media for kaliandra seedlings in nursery and field testing.
\end{abstract}

Key words: Alternative growth media, Caliandra calothyrsus, growth, polybag

\begin{abstract}
ABSTRAK
Penanaman kaliandra (Caliandra calothyrsus Meissn.) secara umum dilakukan dengan menyiapkan bibit dalam wadah plastik (polybag) dengan media tanah permukaan. Penggunaan polybag dalam jumlah besar dapat mencemari lahan hutan karena polybag sulit untuk terdekomposisi. Penelitian ini bertujuan untuk menguji sepuluh komposisi media semai cetak terhadap pertumbuhan bibit kaliandra di persemaian dan lapangan. Penelitian menggunakan Rancangan Acak Kelompok dengan perlakuan komposisi media semai cetak. Parameter yang diuji adalah (1) kekuatan media cetak; (2) pertumbuhan bibit di persemaian dan lapangan. Hasil penelitian menunjukkan bahwa komposisi KM-3 (campuran media kompos 40\%, arang sekam 20\%, tanah 20\%, kaptan 10\%, tapioka 10\%, rhizobium $3 \mathrm{~g}$ ), KM-7 (kompos 30\%, arang sekam 20\%, tanah 30\%, kaptan 10\%, tapioka 10\%, rhizobium 3 g), dan KM-8 (kompos 30\%, arang sekam $20 \%$, tanah $30 \%$, kaptan $10 \%$, tapioka $10 \%$, mikoriza 3 g) memiliki tingkat keutuhan media lebih dari $90 \%$ setelah diuji selama 2 bulan di persemaian. Komposisi KM-3 merupakan media terbaik untuk pertumbuhan tinggi dan diameter bibit kaliandra di persemaian dan lapangan.
\end{abstract}

Kata kunci: Caliandra calothyrsus, media tumbuh alternatif, pertumbuhan, polybag

\section{PENDAHULUAN}

Kaliandra (Caliandra calothyrsus Meissn.) merupakan pohon berukuran kecil tanpa duri yang berasal dari Amerika Tengah dan Meksiko. Jenis ini diintroduksi ke Pulau Jawa pada tahun 1936 dan menjadi tanaman yang menjanjikan karena pertumbuhannya cepat, tahan hama penyakit dan toleran terhadap kekeringan. Kaliandra merupakan jenis serbaguna yang dapat di- 
manfaatkan untuk berbagai kebutuhan, seperti daunnya untuk makanan ternak, bunganya berkembang sepanjang tahun sehingga cocok untuk mendukung budidaya lebah, dan kayunya dapat digunakan untuk pulp dan kayu energi (Syamsuwida, Kurniaty, Putri, \& Suita, 2014; Hendrati \& Hidayati, 2014). Selain itu, tanaman ini juga cocok untuk mengendalikan erosi tanah dan memperbaiki kesuburan tanah karena mampu mengikat nitrogen dan menghasilkan biomassa daun yang tinggi (Orwa, Mutua, Kindt, \& Jamnadass, 2009).

Selama ini penanaman kaliandra umumnya menggunakan bibit dalam wadah plastik (polybag) dengan media tanah (top soil). Penggunaan polybag dalam jumlah besar dapat mencemari lahan hutan karena polybag sulit untuk terdekomposisi (Vaverková, Adamcová, Kotovicová, \& Toman, 2014). Selain itu, penggunaan tanah lapisan atas untuk media secara besar-besaran mengakibatkan kerusakan lingkungan (Landis, \& Morgan, 2009) dan juga kualitas tanah yang digunakan untuk media-pun makin menurun dengan tingkat keasaman tinggi yang mengakibatkan kualitas media bibitnya kurang baik serta memerlukan pupuk yang lebih banyak (Kung'u, Kihara, Mugendi, \& Jaenicke, 2008; Rabileh, Shamshuddin, Panhwar, Rosenani, \& Anuar, 2015). Alternatif lain untuk menggantikan bibit dalam wadah plastik adalah media semai cetak yang mampu meningkatkan keberhasilan persemaian, lebih mudah dalam transportasi dan juga tidak mencemari ling-kungan (SEAMEO-BIOTROP, 2014).

Media semai cetak atau biopot adalah pot yang terbuat dari kompos yang telah matang yang ditambah dengan bahan aditif bukan kimia sebagai perekat (Tikupadang, Nursyamsi, Toaha, Hajar, \& Palalunan, 2011). Media semai cetak dapat berfungsi sebagai wadah bibit sekaligus media tumbuh bagi bibit. Beberapa institusi telah mengembangkan biopot sebagai wadah dan media tumbuh bibit dengan berbagai istilah, seperti media cetak semai oleh BPDAS Sungai Way Seputih (Ayub, \& Batara, 2015) dengan menggunakan media tanah liat, serbuk sabut kelapa, arang sekam dan pasir halus dan pot organik atau biopot oleh BPK Makassar yang menggunakan campuran kompos serbuk gergaji (58\%), tanah liat (25\%), arang sekam (17\%), mikoriza $10 \mathrm{~g}$ dan bakteri pelarut fosfat 3 ml (Tikupadang et al., 2011). Namun kajian mengenai perbandingan komposisi bahan untuk media dalam hubungannya dengan pertumbuhan bibit khususnya di lapangan masing sangat terbatas. Menurut Kung'u et al. (2008) komposisi bahan media berkontribusi terhadap kondisi fisik, kimia dan biologi media yang sangat diperlukan untuk perkembangan bibit secara optimal. Untuk itu, penelitian mengenai kelayakan media cetak semai untuk pembibitan tanaman hutan sangat diperlukan. Tujuan penelitian adalah menguji beberapa komposisi media semai cetak terhadap pertumbuhan bibit kaliandra di persemaian dan lapangan.

\section{METODOLOGI}

\section{A. Tempat Penelitian}

Benih dikumpulkan di tegakan benih kaliandra di Cikajang, Kabupaten Garut pada bulan Maret 2015 dengan mengunduh polong yang telah masak secara fisiologis yang dicirikan dengan kulit polong mengering dan berwarna coklat. Benih diekstraksi secara manual dengan penjemuran hingga polong membuka.

Benih diproses di Laboratorium Teknologi Benih, Balai Penelitian dan Pengembangan Teknologi Perbenihan Tanaman Hutan (BP2TPTH) Bogor. Persemaian dan pengujian bibit dilakukan di Stasiun Penelitian Nagrak selama tiga bulan. Uji lapang media semai cetak 
Eliya Suita, Dede J. Sudrajat, dan Rina Kurniaty

dilakukan di Hutan Penelitian Parung Panjang, BP2TPTH Bogor. Hutan Penelitian Parung Panjang terletak pada $06^{\circ} 20^{\prime} 42^{\prime \prime}$ LS, $106^{\circ} 06^{\prime} 15^{\prime \prime}$ BT dengan ketinggian $52 \mathrm{~m}$ dari permukaan laut (dpl). Tanah di lokasi ini termasuk miskin hara dengan $\mathrm{pH}$ 4,2 dan curah hujan tahunan $2.000 \mathrm{~mm} /$ tahun.

\section{B. Metode}

\section{Persiapan media semai cetak}

Bahan media semai cetak yang berupa kompos, tanah, arang sekam, kaptan (kapur tanaman), dan tapioka dicampurkan sesuai dengan komposisi pada Tabel 1. Media disterilkan dengan cara dijemur di bawah sinar matahari selama dua hari (pukul 9.00-14.00). Pembuatan media semai cetak dilakukan dengan cara mengaduk bahan-bahan tersebut dengan air mendidih (air panas) sehingga merata. Pembuatan media semai cetak dilakukan secara manual dengan bentuk selinder (tinggi $15 \mathrm{~cm}$ dan diameter $10 \mathrm{~cm}$ ). Bagian atas biopot diberi lubang sebagai tempat semai disapih. Penambahan mikoriza dan rhizobium dilakukan pada saat penyapihan.

\section{Pengukuran karakteristik fisik media cetak}

Pengukuran karakteristik fisik media dilakukan dengan meletakkan seratus media semai cetak tanpa bibit per perlakuan komposisi media di rak persemaian di Stasiun Penelitian Nagrak. Selanjutnya, media semai disiram $100 \mathrm{ml}$ air dua kali per hari selama dua bulan. Pengamatan kekuatan media semai cetak dilakukan pada akhir pengujian dengan menghitung jumlah media cetak dengan menggunakan tiga kategori tingkat kerusakan yaitu utuh, retak/patah, dan hancur.

Tabel (Table) 1. Komposisi bahan media semai cetak (Composition of blocked seedling media)

\begin{tabular}{|c|c|}
\hline $\begin{array}{l}\text { Kode } \\
(\text { Code })\end{array}$ & $\begin{array}{l}\text { Perlakuan } \\
\text { (Treatment) }\end{array}$ \\
\hline KM-0 & Top soil (Top soil) \\
\hline KM-1 & $\begin{array}{l}\text { Kompos } 50 \%+\text { arang sekam } 30 \%+\text { kaptan } 15 \%+\text { tapioka } 5 \%+\text { rhizobium } 3 \mathrm{~g} \text { (Compost } 50 \%+ \\
\text { rice hull charcoal } 30 \%+\text { lime } 15 \%+\text { tapioca } 5 \%+\text { rhizobium } 3 \mathrm{~g})\end{array}$ \\
\hline KM-2 & $\begin{array}{l}\text { Kompos } 50 \%+\text { arang sekam } 30 \%+\text { kaptan } 15 \%+\text { tapioka } 5 \%+\text { mikoriza } 3 \mathrm{~g}(\text { Compost } 50 \%+\text { rice } \\
\text { hull charcoal } 30 \%+\text { tapioca } 5 \%+\text { mycorrhizae } 3 \mathrm{~g})\end{array}$ \\
\hline KM-3 & $\begin{array}{l}\text { Kompos } 40 \%+\text { arang sekam } 20 \%+\operatorname{tanah} 20 \%+\text { kaptan } 10 \%+\text { tapioka } 10 \%+\text { rhizobium } 3 \mathrm{~g} \\
\text { (Compost } 40 \%+\text { rice hull charcoal } 20 \%+\text { soil } 20 \%+\text { lime } 10 \%+\text { tapioca } 10 \%+\text { rhizobium } 3 \mathrm{~g} \text { ) }\end{array}$ \\
\hline KM-4 & $\begin{array}{l}\text { Kompos } 40 \%+\text { arang sekam } 20 \%+\operatorname{tanah} 20 \%+\text { kaptan } 10 \%+\text { tapioka } 10 \%+\text { mikoriza } 3 \mathrm{~g} \\
(\text { Compost } 40 \%+\text { rice hull charcoal } 20 \%+\text { soil } 20 \%+\text { lime } 10 \%+\text { tapioca } 10 \% \text { mycorrhizae } 3 \mathrm{~g} \text { ) }\end{array}$ \\
\hline KM-5 & $\begin{array}{l}\text { Kompos } 35 \%+\text { arang sekam } 25 \%+\operatorname{tanah} 25 \%+\text { kaptan } 10 \%+\text { tapioka } 5 \%+\text { rhizobium } 3 \mathrm{~g} \\
\text { (Compost } 35 \%+\text { rice hull charcoal } 25 \%+\text { soil } 25 \%+\text { lime } 10 \%+\text { tapioca } 5 \%+\text { rhizobium } 3 \mathrm{~g} \text { ) }\end{array}$ \\
\hline KM-6 & $\begin{array}{l}\text { Kompos } 35 \%+\text { arang sekam } 25 \%+\operatorname{tanah} 25 \%+\text { kaptan } 10 \%+\text { tapioka } 5 \%+\text { mikoriza } 3 \mathrm{~g} \\
\text { (Compost } 35 \%+\text { rice hull charcoal } 25 \%+\text { soil } 25 \%+\text { lime } 10 \%+\text { tapioca } 5 \%+\text { mycorrhizae } 3 \mathrm{~g} \text { ) }\end{array}$ \\
\hline KM-7 & $\begin{array}{l}\text { Kompos } 30 \%+\text { arang sekam } 20 \%+\operatorname{tanah} 30 \%+\text { kaptan } 10 \%+\text { tapioka } 10 \%+\text { rhizobium } 3 \mathrm{~g} \\
\text { (Compost } 30 \%+\text { rice hull charcoal } 20 \%+\text { soil } 30 \%+\text { lime } 10 \%+\text { tapioca } 10 \%+\text { rhizobium } 3 \mathrm{~g} \text { ) }\end{array}$ \\
\hline KM-8 & $\begin{array}{l}\text { Kompos } 30 \%+\text { arang sekam } 20 \%+\operatorname{tanah} 30 \%+\text { kaptan } 10 \%+\text { tapioka } 10 \%+\text { mikoriza } 3 \mathrm{~g} \\
\text { (Compost } 30 \%+\text { rice hull charcoal } 20 \%+\text { soil } 30 \%+\text { lime } 10 \%+\text { tapioca } 10 \%+\text { mycorrhizae } 3 \mathrm{~g} \text { ) }\end{array}$ \\
\hline KM-9 & $\begin{array}{l}\text { Kompos } 25 \%+\text { arang sekam } 20 \%+\operatorname{tanah} 35 \%+\text { kaptan } 15 \%+\text { tapioka } 5 \%+\text { rhizobium } 3 \mathrm{~g} \\
\text { (Compost } 25 \%+\text { rice hull charcoal } 20 \%+\text { soil } 35 \%+\text { lime } 15 \%+\text { tapioca } 5 \%+\text { rhizobium } 3 \mathrm{~g} \text { ) }\end{array}$ \\
\hline KM-10 & $\begin{array}{l}\text { Kompos } 25 \%+\text { arang sekam } 20 \%+\operatorname{tanah} 35 \%+\text { kaptan } 15 \%+\text { tapioka } 5 \%+\text { mikoriza } 3 \mathrm{~g} \\
\text { (Compost } 25 \%+\text { rice hull charcoal } 20 \%+\text { soil } 35 \%+\text { lime } 15 \%+\text { tapioca } 5 \%+\text { mycorrhizae } 3 \mathrm{~g} \text { ) }\end{array}$ \\
\hline
\end{tabular}




\section{Rancangan penelitian}

a. Rancangan dan pengukuran pertumbuhan bibit di persemaian

Benih kaliandra ditabur pada bak kecambah dengan media campuran tanah dan pasir $(1: 1, \mathrm{v} / \mathrm{v})$. Sebelum ditabur, benih direndam air panas $\left(80^{\circ} \mathrm{C}\right)$ dan dibiarkan dingin selama 24 jam (Sudrajat, Nurhasybi, \& Yulianti, 2015). Setelah 14 hari, semai telah siap disapih. Semai dengan ukuran yang seragam $\pm 3 \mathrm{~cm}$ dipindahkan ke dalam media semai cetak dan media dalam polybag dengan komposisi media (kontrol) seperti pada Tabel 1.

Bibit dalam media semai cetak dan polybag disusun sesuai dengan komposisi bahannya dalam Rancangan Acak Kelompok dengan sebelas perlakuan (Tabel 1) dan empat kelompok yang terdiri dari seratus bibit setiap kelompok. Pengukuran tinggi dan diameter bibit awal dilakukan seminggu setelah penyapihan sehingga bibit lebih stabil dan mulai beradaptasi dengan media baru. Pengukuran dilakukan saat bibit ber umur dua bulan meliputi: tinggi, diameter pangkal batang, dan indek kekokohan bibit. Pertumbuhan tinggi dan diameter diperoleh dari selisih hasil pengukuran awal dan hasil pengukuran akhir (umur dua bulan). Indek kekokohan bibit merupakan hasil pembagian tinggi bibit dengan diameter bibit (Budiman, Sudrajat, Lee, \& Kim, 2015). Pengukuran berat kering bibit dilakukan dengan mengambil enam bibit secara acak. Berat kering diperoleh dengan mengeringkan bibit pada suhu $70^{\circ} \mathrm{C}$ selama 48 jam. Rasio akar pucuk dihitung dengan membagi berat kering akar dengan berat kering pucuk.

\section{b. Rancangan dan pengukuran bibit di lapangan}

Uji lapang media semai cetak dilakukan dengan Rancangan Acak Kelompok dengan tiga kelompok uji dan setiap kelompok terdiri dari seratus bibit.
Penanaman dilakukan dengan ukuran lubang tanam $30 \mathrm{~cm} \times 30 \mathrm{~cm} \times 30 \mathrm{~cm}$ dan jarak tanam $3 \mathrm{~m} \times 3 \mathrm{~m}$. Pengukuran pertumbuhan persen hidup, tinggi dan diameter pangkal batang bibit dilakukan pada umur tanaman enam bulan setelah tanam.

\section{Analisis data}

Penentuan tingkat kekuatan media semai cetak dilakukan secara deskriptif dengan kategori jumlah media cetak yang utuh, retak/patah, dan hancur. Analisis ragam dilakukan untuk menguji pengaruh perlakuan berbagai komposisi bahan media cetak semai terhadap pertumbuhan bibit di persemaian dan lapangan. Uji Duncan dilakukan bila hasil analisis ragam data perlakuan berbagai komposisi bahan media cetak semai berpengaruh nyata terhadap parameter yang diamati.

\section{III.HASIL DAN PEMBAHASAN}

\section{A. Hasil}

1. Ketahanan media terhadap penyiraman di persemaian

Pengujian ketahanan media terhadap perlakuan di persemaian terutama penyiraman yang dilakukan pada bulan Juni sampai Juli 2015 menunjukkan bahwa komposisi media berpengaruh signifikan terhadap ketahanan media. Hasil uji lanjut menunjukkan bahwa KM7 (kompos 30\% + arang sekam 20\% + tanah 30\% + kaptan 10\% + tapioka 10\% + rhizobium $3 \mathrm{~g}$ ), KM-3 (kompos 40\% + arang sekam $20 \%+$ tanah $20 \%+$ kaptan $10 \%+$ tapioka $10 \%+$ rhizobium $3 \mathrm{~g}$ ), dan KM-8 (kompos 40\% + arang sekam $20 \%+\operatorname{tanah} 20 \%+$ kaptan $10 \%+$ tapioka $10 \%+$ mikoriza $3 \mathrm{~g}$ ) memberikan ketahanan media terbaik dengan jumlah media semai cetak yang utuh paling banyak (lebih dari 90\%). KM-1 (kompos $50 \%+$ arang sekam 30\% + kaptan 15\% + tapioka $5 \%+$ rhizobium 3 g) yang merupakan komposisi media tanpa tanah 
Eliya Suita, Dede J. Sudrajat, dan Rina Kurniaty

memiliki kekuatan yang paling rendah dengan jumlah media semai cetak utuh terendah (hingga akhir pengamatan 54\%) (Gambar 1).

\section{Pertumbuhan bibit di persemaian}

Komposisi media bahan penyusun media semai cetak berpengaruh nyata terhadap pertumbuhan tinggi, diameter, indeks kekokohan bibit, berat kering akar dan rasio pucuk akar bibit kaliandra di persemaian, kecuali pada berat kering pucuk dan berat kering total bibit tidak berpengaruh nyata. Komposisi media KM-3 (kompos 40\% + arang sekam 20\% + tanah $20 \%+$ kaptan $10 \%+$ tapioka $10 \%+$ rhizobium $3 \mathrm{~g}$ ) memberikan hasil terbaik untuk tinggi, diameter dan berat kering akar bibit di persemaian. Secara umum, bibit kaliandra yang ditumbuhkan dalam media semai cetak memiliki pertumbuhan yang lebih baik dibandingkan dengan bibit dalam polybag.

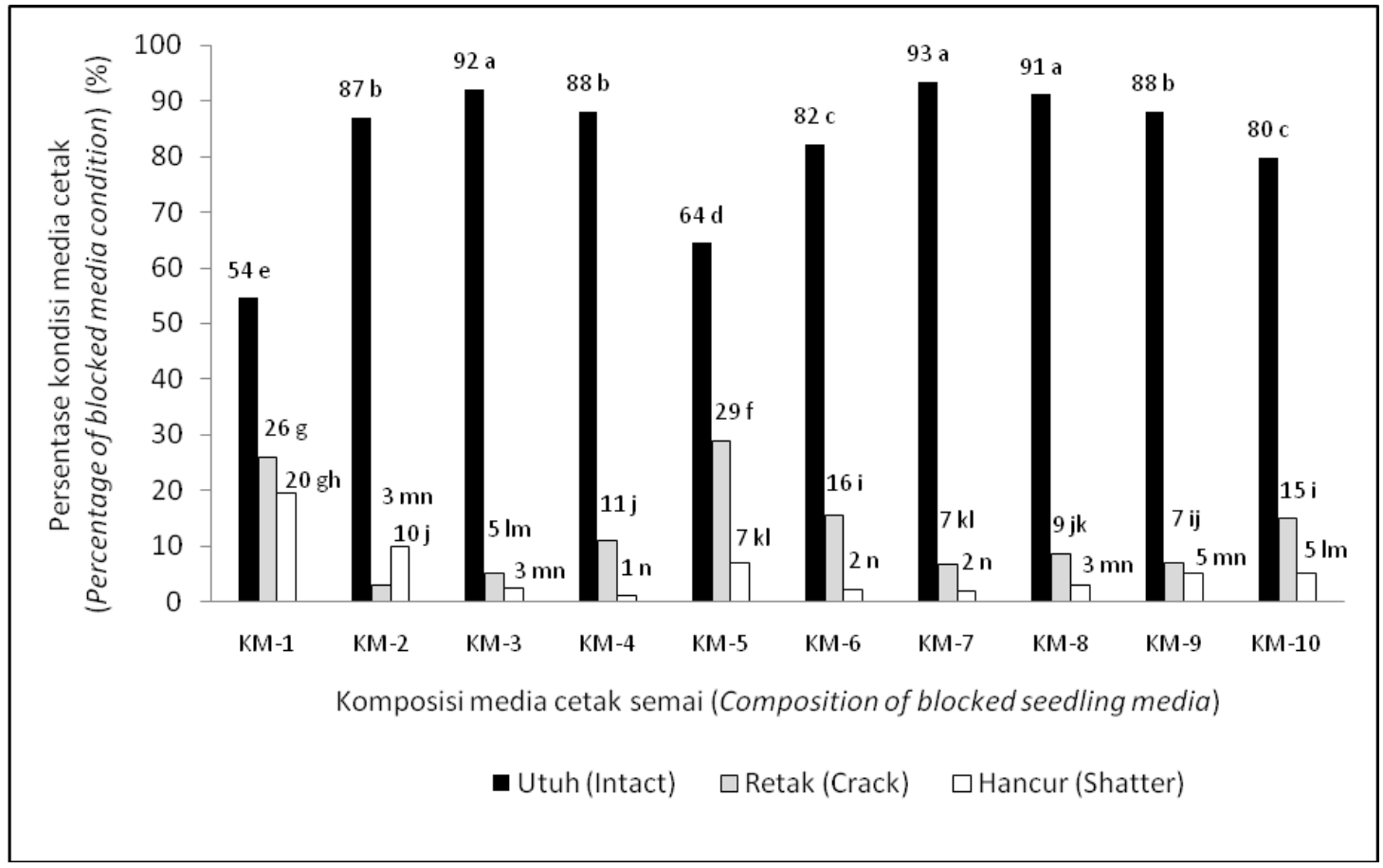

Keterangan/Remarks: Angka yang diikuti huruf yang sama pada grafik batang yang sama menunjukan tidak berbeda nyata pada tingkat kepercayaan 95\%/Figures followed by the same letter on the chart values are not significanlyt different at 95\% confident level.

Gambar (Figure) 1. Kondisi media semai cetak setelah perlakuan penyiraman selama 2 bulan di persemaian (Condition of blocked seedling media after watering treatment for 2 months at nursery) 
Tabel (Table) 2. Pertumbuhan bibit kaliandra umur tiga bulan pada berbagai komposisi media semai cetak di persemaian (Growth of kaliandra seedlings at two months age on e various blocked seedling media in nursery)

\begin{tabular}{|c|c|c|c|c|c|c|c|}
\hline $\begin{array}{c}\text { Komposisi } \\
\text { media } \\
\text { (Composition } \\
\text { of media) }\end{array}$ & $\begin{array}{c}\text { Tinggi } \\
\text { (Height) } \\
(\mathrm{cm})\end{array}$ & $\begin{array}{c}\text { Diameter } \\
(\mathrm{mm})\end{array}$ & $\begin{array}{c}\text { Indeks } \\
\text { kekokohan } \\
\text { (Sturdiness } \\
\text { quotient) }\end{array}$ & $\begin{array}{c}\text { Berat } \\
\text { kering } \\
\text { pucuk } \\
\text { (Shoot } \\
\text { biomass) }\end{array}$ & $\begin{array}{c}\text { Berat } \\
\text { kering } \\
\text { Akar (Root } \\
\text { Biomass) } \\
\text { (gram) }\end{array}$ & $\begin{array}{c}\text { Berat } \\
\text { kering total } \\
\text { (Total } \\
\text { biomass) } \\
\text { (gram) }\end{array}$ & $\begin{array}{c}\text { Rasio pucuk } \\
\text { akar (Shoot- } \\
\text { root ratio }\end{array}$ \\
\hline $\begin{array}{c}\text { Kontrol } \\
\text { (Control) }\end{array}$ & $22,6 \pm 7,6 \mathrm{~d}$ & $3,5 \pm 0,9 \mathrm{~cd}$ & $6,4 \pm 1,6 \mathrm{bcd}$ & 2,950 & $0,425 \mathrm{c}$ & 3,385 & $7,14 \mathrm{abc}$ \\
\hline KM-1 & $26,7 \pm 7,3 \mathrm{bc}$ & $4,1 \pm 1,1 \quad b c$ & $6,6 \pm 1,7 \mathrm{bcd}$ & 3,510 & $0,492 \mathrm{bc}$ & 4,002 & $7,42 \mathrm{abc}$ \\
\hline KM-2 & $26,4 \pm 8,9 \mathrm{bc}$ & $4,0 \pm 1,2 \mathrm{bc}$ & $6,5 \pm 1,6 \mathrm{bcd}$ & 3,449 & $0,497 \mathrm{bc}$ & 4,011 & $6,08 \mathrm{bc}$ \\
\hline KM-3 & $32,2 \pm 5,5 \mathrm{a}$ & $4,5 \pm 0,7$ a & $7,1 \pm 1,1 \quad b$ & 3,660 & 0,652 a & 4,312 & $5,61 \mathrm{c}$ \\
\hline KM-4 & $25,3 \pm 6,6 \mathrm{~cd}$ & $4,1 \pm 0,9 \mathrm{bc}$ & $6,1 \pm 1,1 \mathrm{cde}$ & 3,653 & $0,436 \mathrm{bc}$ & 4,090 & $8,39 \mathrm{ab}$ \\
\hline KM-5 & $27,3 \pm 7,4 \mathrm{~cd}$ & $4,0 \pm 0,7 \quad \mathrm{bc}$ & $6,9 \pm 1,9 \mathrm{bc}$ & 3,243 & $0,443 \mathrm{bc}$ & 3,686 & $7,41 \mathrm{zbc}$ \\
\hline KM-6 & $24,7 \pm 5,7 \mathrm{~cd}$ & $4,1 \pm 0,6$ bc & $6,0 \pm 1,3 \mathrm{de}$ & 3,359 & $0,562 \mathrm{~b}$ & 3,921 & $5,97 \mathrm{c}$ \\
\hline KM-7 & $22,2 \pm 5,6 \mathrm{~d}$ & $3,9 \pm 0,8 \mathrm{~cd}$ & $5,9 \pm 1,8 \mathrm{de}$ & 2,593 & $0,476 \mathrm{bc}$ & 3,060 & $5,37 \mathrm{c}$ \\
\hline KM-8 & $25,2 \pm 7,0 \mathrm{~cd}$ & $4,3 \pm 0,9 \mathrm{ab}$ & $6,1 \pm 2,6 \mathrm{de}$ & 3,090 & $0,483 \mathrm{bc}$ & 3,573 & $6,45 \mathrm{bc}$ \\
\hline KM-9 & $24,2 \pm 5,1 \mathrm{~cd}$ & $4,4 \pm 0,9 \mathrm{ab}$ & $5,6 \pm 1,7 \mathrm{e}$ & 3,566 & $0,496 \mathrm{bc}$ & 4,063 & $7,30 \mathrm{abc}$ \\
\hline KM-10 & $28,6 \pm 6,1 \mathrm{~b}$ & $3,7 \pm 0,8 \mathrm{~cd}$ & $8,0 \pm 2,2$ a & 4,273 & $0,466 \mathrm{bc}$ & 4,740 & $9,31 \mathrm{a}$ \\
\hline
\end{tabular}

Keterangan (Remarks): Angka-angka yang diikuti oleh huruf yang $\mathrm{s}$ ama pada kolom yang sama tidak berbeda nyata berdasarkan uji Duncan pada tingkat kepercayaan $95 \%$ (Values within a similar column followed by the same letter are not significantly different in accordance with the results of the $95 \%$ confident level Duncan's multiple range test)

\section{Pertumbuhan bibit uji lapang}

Komposisi bahan penyusun media semai cetak berpengaruh nyata terhadap pertumbuhan tinggi dan diameter tanaman umur enam bulan, sedangkan untuk persen hidup bibit, komposisi bahan media semai cetak tidak berpengaruh nyata. Pertumbuhan bibit pada umur enam bulan di Hutan Penelitian
Parung Panjang dari berbagai komposisi media semai cetak menunjukkan bahwa KM-3 (kompos 40\% + arang sekam 20\% + tanah $20 \%+$ kaptan $10 \%+$ tapioka $10 \%+$ rhizobium $3 \mathrm{~g}$ ) memberikan pertumbuhan terbaik (Tabel 3). Kecenderungan pertumbuhan ini sejalan dengan pertumbuhan bibit sewaktu di persemaian.

Tabel (Table) 3. Pertumbuhan bibit kaliandra pada beberapa komposisi media semai cetak pada umur 6 bulan setelah tanam (Gwoth performance of kaliandra on various block ed seedling media at 6 months after planting)

\begin{tabular}{lccc}
\hline $\begin{array}{c}\text { Komposisi media } \\
\left(\begin{array}{c}\text { Composition of } \\
\text { media })\end{array}\right.\end{array}$ & $\begin{array}{c}\text { Tinggi } \\
(\text { Height }) \\
(\mathrm{m})\end{array}$ & $\begin{array}{c}\text { Diameter } \\
(\mathrm{mm})\end{array}$ & $\begin{array}{c}\text { Persen hidup (Survival) } \\
(\%)\end{array}$ \\
\hline Kontrol (Control) & $78,5 \pm 47,0 \mathrm{e}$ & $9,3 \pm 3,1 \mathrm{f}$ & $88,9 \pm 11,1$ \\
KM-1 & $121,2 \pm 57,8 \mathrm{abc}$ & $11,0 \pm 2,9 \mathrm{cde}$ & $96,3 \pm 6,4$ \\
KM-2 & $129,5 \pm 50,0 \mathrm{ab}$ & $12,1 \pm 3,0 \mathrm{a}-\mathrm{d}$ & $96,3 \pm 6,4$ \\
KM-3 & $136,5 \pm 46,9 \mathrm{a}$ & $13,6 \pm 3,4 \mathrm{a}$ & $96,3 \pm 12,8$ \\
KM-4 & $94,3 \pm 50,9 \mathrm{cde}$ & $10,6 \pm 2,8 \mathrm{def}$ & $96,3 \pm 6,4$ \\
\hline
\end{tabular}


Eliya Suita, Dede J. Sudrajat, dan Rina Kurniaty

Tabel (Table) 3. Lanjutan (Continuation)

\begin{tabular}{lccc}
\hline $\begin{array}{c}\text { Komposisi media } \\
\left(\begin{array}{c}\text { Composition of } \\
\text { media })\end{array}\right.\end{array}$ & $\begin{array}{c}\text { Tinggi } \\
(\text { Height }) \\
(\mathrm{m})\end{array}$ & $\begin{array}{c}\text { Diameter } \\
(\mathrm{mm})\end{array}$ & $\begin{array}{c}\text { Persen hidup (Survival) } \\
(\%)\end{array}$ \\
\hline KM-5 & $106,2 \pm 46,7 \mathrm{bcd}$ & $11,7 \pm 2,5 \mathrm{bcd}$ & $92,6 \pm 6,4$ \\
KM-6 & $106,3 \pm 36,0 \mathrm{bcd}$ & $11,6 \pm 2,7 \mathrm{bcd}$ & $100,0 \pm 0,0$ \\
KM-7 & $124,3 \pm 38,8 \mathrm{ab}$ & $12,5 \pm 2,9 \mathrm{abc}$ & $96,3 \pm 6,4$ \\
KM-8 & $103,7 \pm 37,0 \mathrm{be}$ & $10,7 \pm 2,4 \mathrm{def}$ & $100,0 \pm 0,0$ \\
KM-9 & $126,9 \pm 42,0 \mathrm{ab}$ & $12,8 \pm 3,0 \mathrm{ab}$ & $85,2 \pm 12,8$ \\
KM-10 & $90,1 \pm 43,6 \mathrm{de}$ & $9,8 \pm 3,0 \mathrm{ef}$ & $90,75 \pm 4,5$ \\
\hline
\end{tabular}

Keterangan (Remarks): Angka-angka yang diikuti oleh huruf yang s ama pada kolom yang sama tidak berbedanyata berdas arkan uji Duncan pada tingkat kepercayaan 95\%/Values within a similar column followed by the same letter are not significantly different in accordance with the results of the $95 \%$ confident level Duncan's multiple range test

Media tumbuh bibit harus tetap utuh sehingga mampu memasok air, udara, unsur hara, ke akar bibit dan dukungan fisik selama bibit masih di persemaian (Landis \& Morgan, 2009; Jacobs, Landis, \& Luna, 2015; Tsakaldimi, \& Ganatsas, 2016). Media tumbuh juga harus mampu meningkatkan kemampuan bibit untuk tumbuh di lapangan sehingga media tersebut harus dirancang untuk memberikan kemampuan sistem perakaran untuk menumbuhkan akar-akar baru dan berkembang setelah ditanam di lapangan.

Untuk pertumbuhan bibit di persemaian, komposisi KM-3 (kompos 40\% + arang sekam $20 \%+$ tanah $20 \%+$ kaptan $10 \%$ + tapioka $10 \%$ + rhizobium 3 g) memberikan hasil terbaik untuk tinggi dan diameter bibit di persemaian. Komposisi media tanpa tanah (KM-1 dan KM-2) memiliki pori yang besar. Menurut Sudrajat, Nurhasybi, Suita, \& Kurniaty (2015) komposisi media tanpa tanah memiliki kapasitas tukar kation (KTK) yang rendah, yaitu kurang dari $11,11 \mathrm{cmol} / \mathrm{kg}$, sedangkan komposisi media yang dicampur tanah mempunyai KTK yang tinggi $(\mathrm{KTK}>21,34 \mathrm{meq} / 100$ g). Media dengan KTK tinggi mampu menyerap dan menyediakan unsur hara lebih baik daripada media dengan KTK rendah, karena unsur-unsur hara terdapat dalam kompleks jerapan koloid, maka unsur-unsur hara tersebut tidak mudah hilang tercuci oleh air (Soewandita, 2008). Hasil yang sama juga diperoleh pada uji penanaman di lapangan, komposisi KM-3 menghasilkan pertumbuhan terbaik. Secara umum bibit dalam media cetak semai mempunyai penampilan yang lebih baik dibandingkan dengan bibit dalam polybag. Beberapa penelitian sebelumnya juga menunjukkan bahwa media semai cetak mampu meningkatkan perkecambahan, lebih ringan dari bibit pada polybag dan lebih mudah dalam transportasi (SEAMEO BIOTROP, 2014; Ayub \& Batara, 2015).

Pertumbuhan pada media polybag relatif lebih rendah dibandingkan bibit pada biopot. Hasil ini berbeda dengan Tikupadang et al. (2011) yang melaporkan bahwa bibit pada polybag dengan media tanah dan sekam $(5: 2, \mathrm{v} / \mathrm{v})$ memiliki pertumbuhan tinggi dan diameter lebih baik dibandingkan dengan bibit pada media cetak dengan media campuran kompos serbuk gergaji (58\%), tanah liat (25\%), arang sekam (17\%), mikoriza $10 \mathrm{~g}$ dan bakteri pelarut fosfat 3 ml. Diduga pada penelitian Tikupadang et al. (2011) kompos yang digunakan belum matang. Pada penelitian ini diduga bibit dalam polybag mempunyai komposisi bahan organik lebih sedikit. Keberadaan bahan organik dalam media semai sangat penting karena bahan 
organik mempunyai dampak yang penting terhadap karakteristik fisik, kimia dan biologi media (Kung'u et al., 2008; Osaigbovo, Nwaoguala, \& Falodun, 2010). Bahan organik juga mempunyai beberapa fungsi, seperti menyediakan unsur hara penting yang diperlukan tanaman (Tsakaldimi, \& Ganatsas, 2016), memperbaiki kapasitas menahan air (Mathowa, Hababa, Mpofu, Legwaila, \& Mojeremane, 2014), mem-perbaiki agregasi dan menjaga kekompakan media (Jacobs, Landis, \& Luna, 2015). Dari berbagai bahan organik, kompos merupakan bahan terbanyak. Menurut (Kung'u et al., 2008), komposisi kompos yang relatif tinggi $(30 \%)$ pada media semai mampu meningkatkan persen hidup $(52 \%)$ dan pertumbuhan tinggi bibit (89\%) Tamarindus indica dibandingkan dengan media tanah pertanian.

Pada media semai cetak juga ditambahkan kaptan yang mengandung unsur $\mathrm{Ca}$ yang dapat meningkatkan $\mathrm{pH}$ tanah. Kaptan juga dapat meningkatkan ketersediaan fosfor (P) dan molibium (Mo), serta mampu menetralkan senyawa beracun dan menekan penyakit tanaman (Wijaya, 2011). Penambahan rhizobium pada saat penyapihan juga memberikan hasil positif terhadap pertumbuhan bibit kaliandra baik di persemaian maupun lapangan. Hasil serupa juga dilaporkan (Kurniaty, \& Bustomi, 2013) pada bibit kaliandra dalam polybag. Rhizobium merupakan mikroba penambat $\mathrm{N}_{2}$ yang hidup bersimbiosis pada tanaman inang dari famili Leguminoceae dengan membentuk bintil pada akarnya (Nofrianti, 2011; Ritika, \& Utpal, 2014; Sari, \& Prayudyaningsih, 2015). Unsur N secara umum dapat memacu pertumbuhan tanaman terutama pada fase vegetatif, pembentukan klorofil, asam amino, lemak, enzim dan persenyawaan lainnya, merangsang perkembangbiakan mikroorganisme (Soewandita, 2008; Sonbai, Prajitno, \& Syukur, 2013; Ghaly, \&
Ramakrishnan, 2015) Sementara penambahan mikoriza pada media yang sama mempunyai pertumbuhan bibit lebih rendah dibandingkan dengan pertumbuhan bibit pada media yang diberi rhizobium. Hasil serupa dilaporkan (Kurniaty, \& Bustomi, 2013) pada bibit kalindra dan (Danu, Kurniaty, \& Nugraheni, 2016) pada bibit nyawai dalam polybag yang diberi mikoriza menunjukkan hasil yang tidak efektif. Hal tersebut terjadi karena mikoriza akan berperan ketika terjadi perluasan volume tanah. Pada media yang terbatas, hipa eksternal tidak dapat memperluas diri dan penyerapan unsur hara tidak terjadi, sementara tanaman sebagai inang tetap harus memasok unsur hara kepada mikoriza. Kondisi juga bisa disebabkan oleh adanya infeksi cendawan lain yang lebih adaptif sehingga menciptakan persaingan dengan cendawan mikoriza yang diinokulasikan (Elfiati, \& Siregar, 2010). Margarettha (2010) dan Prayudyaningsih, \& Sari (2016) menambahkan bahwa mikoriza terlihat pengaruhnya terhadap pertumbuhan bibit apabila kondisi lingkungannya esktrim.

\section{IV.KESIMPULAN DAN SARAN}

\section{A. Kesimpulan}

Komposisi media KM-3 (kompos $40 \%+$ arang sekam $20 \%+\operatorname{tanah} 20 \%+$ kaptan $10 \%+$ tapioka $10 \%+$ rhizobium 3 g), KM-7 (kompos 30\% + arang sekam $20 \%+\operatorname{tanah} 30 \%+$ kaptan $10 \%+$ tapioka $10 \%$ + rhizobium $3 \mathrm{~g}$ ), dan KM-8 (kompos 40\% + arang sekam 20\% + tanah $20 \%+$ kaptan $10 \%+$ tapioka $10 \%$ + mikoriza 3 g) memiliki tingkat keutuhan media lebih dari $90 \%$ setelah diuji selama dua bulan di persemaian. Media cetak tersebut mempunyai komposisi bahan perekat (tapioka) lebih tinggi (komposisi tapioka 10\%). Komposisi KM-3 (kompos 40\% + arang sekam $20 \%+\operatorname{tanah} 20 \%+$ kaptan $10 \%+$ 
Eliya Suita, Dede J. Sudrajat, dan Rina Kurniaty

tapioka $10 \%+$ rhizobium $3 \mathrm{~g}$ ) memberikan hasil terbaik untuk pertumbuhan tinggi dan diameter bibit di persemaian. Hal serupa terjadi pada uji penanaman di lapangan, komposisi KM-3 menghasilkan pertumbuhan terbaik. Penggunaan media tanam berupa media cetak mempunyai prospek yang baik untuk diterapkan di lapangan.

\section{B. Saran}

Untuk mengurangi dampak negatif terhadap lingkungan, maka dalam pembuatan bibit tanaman disarankan menggunakan media tanam cetak.

\section{UCAPAN TERIMA KASIH}

Penelitian ini dibiayai dari DIPA APBN Balai Penelitian dan Pengembangan Teknologi Perbenihan Hutan tahun 2015-2016. Penulis mengucapkan terima kasih kepada Bapak Muhammad, Adim, Maman sebagai penjaga Hutan Penelitian Parung Panjang dan kepada Bapak Nurkim, Ibu Eneng Baeni sebagai teknisi litkayasa Balai Penelitian dan Pengembangan Teknologi Perbenihan Tanaman Hutan yang banyak membantu dalam penelitian ini.

\section{DAFTAR PUSTAKA}

Ayub, M., \& Batara, I. (2015). Peran $B P D A S$ dalam peningkatan produktivitas hutan rakyat. Prosiding Seminar Teknologi Perbenihan, Silvikultur, dan Kelembagaan dalam Peningkatan Produktivitas Hutan dan Lahan. Bandar Lampung: Pusat Penellitian dan Pengembangan Hutan, p 199206.

Budiman, B., Sudrajat, D.J., Lee, D.K., \& Kim, Y.S. (2015). Effect of initial morphology on field performance in white jabon seedlings at Bogor, Indonesia. Forest Science and
Technology, 11(4), 206-211. http://doi.org/10.1080/21580103.201 5.1007897

Danu, Kurniaty, R., \& Nugraheni, Y.M.M.A. (2016). Penggunaan mikoriza dan pupuk NPK dalam pembibitan nyawai (Ficus variegate Blume). Jurnal Perbenihan Tanaman Hutan, 4(2), 95-107.

Elfiati, D., \& Siregar, E.B.M. (2010). Pemanfaatan kompos tandan kosong sawit sebagai campuran media tumbuh dan pemberian mikoriza pada bibit mindi (Melia azedarach L.). J. Hidrolitan, 1(1), 11-19.

Ghaly A., \& Ramakrishnan, V.V. (2015). Nitrogen sources and cycling in the ecosystem and its role in air, water and soil pollution: A critical review. Journal of Pollution Effects \& Control, 3(2), 1-26. http://doi.org/10.4172/23754397.1000136

Hendrati, R.L., \& Hidayati, N. (2014). Budidaya kaliandra (Calliandra calothyrsus) untuk bahan baku sumber energi. Bogor: IPB Press.

Jacobs, D.F., Landis, T.D., \& Luna, T. (2015). Growing media. In Nursery manual for native plants: A guide for tribal nurseries. Washington, D.C.: U.S. Department of Agriculture, Forest Service.

Kung'u, J.B., Kihara, J., Mugendi, D.N., \& Jaenicke, H. (2008). Effect of small-scale farmers' tree nursery growing medium on agroforestry tree seedlings' quality in Mt. Kenya region. Scientific Research and Essays, 3(8), 359-364. http://doi.org/http://dx.doi.org/10.10 07/s10705-011-9423-7

Kurniaty, R., \& Bustomi, S. (2013). Penggunaan rhizobium dan mikoriza dalam pertumbuhan bibit kaliandra (Calliandra callothyrsus) umur 5 
bulan Jurnal Perbenihan Tanaman Hutan, 1(2), 71-81.

Landis, T.D., \& Morgan, N. (2009). Growing media alternatives for forest and native plant nurseries. In: Dumroese RK, Riley LE (eds) National Proceedings: Forest and Conservation Nursery Associations. USDA Forest Service Proceedings, 26-31.

Margarettha. (2010). Pemanfaatan tanah bekas tambang batubara dengan pupuk hayati mikoriza sebagai media tanam jagung manis. $J$. Hidrolitan, 1(3), 110.

Mathowa, T., Hababa, K., Mpofu, C., Legwaila, G.M., \& Mojeremane, W. (2014). Influence of different potting media on the growth of pod mahogany (Afzelia quanzensis) seedlings. Int. J. Adv. Res. Biol.Sci. International Journal of Advanced Research in Biological Sciences, 1(7), 105-113. Retrieved from www.ijarbs.com

Nofrianti. (2011). Peranan rhizobium dalam meningkatkan ketersediaan nitrogen bagi tanaman kedelai. AgronobiS, 3(5), 35-42.

Orwa, C., Mutua, A., Kindt, R., \& Jamnadass, R. (2009). Calliandra calothyrsus Meissner. Agroforestree Database:a tree reference and selection guide, pp. 1-6.

Osaigbovo, A.U., Nwaoguala, C.N.C., \& Falodun, J.E. (2010). Evaluation of potting media for the production of pepper fruit (Dennetia tripetala) seedlings, African Journal of General Agriculture, 6(2), 47-51.

Prayudyaningsih, R., \& Sari, R. (2016). Aplikasi fungi mikoriza arbuskula (FMA) dan kompos untuk meningkatkan pertumbuhan jati (Tectona grandis Linn f.) pada media tanah bekas tambang kapur.
Jurnal Penelitian Kehutanan

Wallaceae, 5(1), 37-46.

Rabileh, M.A., Shamshuddin, J., Panhwar, Q.A., Rosenani, A.B., \& Anuar, A.R. (2015). Effects of biochar and/or dolomitic limestone application on the properties of Ultisol cropped to maize under glasshouse conditions. Canadian Journal of Soil Science, 95(1), 3747. http://doi.org/10.4141/cjss-2014067

Sari, R. \& Prayudyaningsih. (2015). Rhizobium: Pemanfaatannya sebagai bakteri penambat nitrogen. Info Teknis EBONI, 12(1), 51-64.

SEAMEO BIOTROP. (2014). Blok media semai, media penanaman bibit lebih praktis. SEAMEO BIOTROP, Bogor.

Ritika, B., \& Utpal, D. (2014). Biofertilizer, a way towards organic agriculture: A review. African Journal of Microbiology Research, 8(24), 2332-2343. http://doi.org/10.5897/AJMR2013.6 374

Soewandita. (2008). Studi kesuburan tanah dan analisis kesesuian lahan untuk komoditas tanaman perkebunan di Kabupaten Bengkalis. Jurnal Sains dan Teknologi Indonesia, 10(2), 128133.

Sonbai, J.H.H., Prajitno, D., \& Syukur. A. (2013). Pertumbuhan dan hasil jagung pada berbagai pemberian pupuk nitrogen di lahan kering regosol. Jurnal Pertanian, 16(1), 77-89.

Sudrajat, D, J., Nurhasybi, Suita, E. \& Kurniaty, R. (2015). Teknologi biopot dan direct seeding untuk rehabilitasi lahan kritis. Laporan Hasil Penelitian Tahun 2015, Balai Penelitian Teknologi Perbenihan Tanaman Hutan. Bogor.. 
Eliya Suita, Dede J. Sudrajat, dan Rina Kurniaty

Syamsuwida, D., Kurniaty, R., Putri, K.P., \& Suita, E. (2014). Kaliandra (Calliandra callothyrsus) as a timber for energy: In a point of view of seeds and seedlings procurement. Energy Procedia, 47, 62-70. http://doi.org/10.1016/j.egypro.2014 .01 .197

Tsakaldimi, M., \& Ganatsas, P. (2016). A synthesis of results on wastes as potting media substitutes for the production of native plant species, 147-163.

http://doi.org/10.21750/REFOR.1.08 .8

Tikupadang, H., Nursyamsi, Toaha, A.Q., \& Hajar, P. (2011). Pemanfaatan mikroba dalam biopoting untuk mendukung bioreklamasi lahan bekas tambang kapur. Laporan Hasil Penelitian Balai Penelitian Kehutanan Makasssar.

Vaverková, M., Adamcová, D., Kotovicová, J., \& Toman, F. (2014).
Evaluation of biodegradability of plastics bags in composting conditions. Ecological Chemistry and Engineering S, 21(1), 45-57. http://doi.org/10.2478/eces-20140004

Wahyudi. (2009). Karakteristik pati ubi kayu (Manihot esculenta Crantz) varietas mentega untuk pembuatan edible film dengan penambahan sodium tripolyphosphate. Surakarta Fakultas Pertanian, Universitas Sebelas Maret. Retrieved from https://digilib.uns.ac.id/...=/Karakter isasi-pati-ubi-kayu-manihot-esc

Wijaya, A. (2011). Pengaruh pemupukan dan pemberian kapur terhadap pertumbuhan dan daya hasil kacang tanah (Arachis hypogaea L.). Bogor: Departemen Agronomi dan Holtikultura,Fakultas Pertanian, Institut Pertanian Bogor. p 1-60. 